Original Article

\title{
Limiting amino acids supplementation in low crude protein diets and their impacts on growth performance and carcass composition in Labeo rohita (rohu) adult fish
}

\author{
Limitação da suplementação de aminoácidos em dietas com baixo teor de proteína \\ bruta e seus impactos no desempenho de crescimento e composição da carcaça em \\ peixes adultos Labeo rohita (rohu)
}

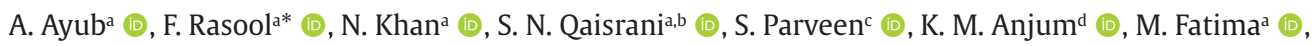 \\ Matiullah $^{\mathrm{a}}$ (D), S. Mahmood ${ }^{\mathrm{a}}$ (D) and T. Zulfiqar ${ }^{\mathrm{a}}$ (D) \\ aUniversity of Veterinary \& Animal Sciences, Faculty of Fisheries \& Wildlife, Department of Fisheries \& Aquaculture, Lahore, Pakistan \\ bUniversity of Veterinary and Animal Sciences, Faculty of Animal Production Technology, Department of Animal Nutrition, Lahore, Pakistan \\ cUniversity of Agriculture, Faculty of Sciences, Department of Zoology, Wildlife \& Fisheries, Faisalabad, Pakistan \\ dUniversity of Veterinary \& Animal Sciences, Faculty of Fisheries \& Wildlife, Department of Fisheries \& Aquaculture, Lahore, Pakistan
}

\begin{abstract}
Ninety days study was conducted in hapas installed in earthen ponds. Fish of an average initial weight (220g) were evenly distributed in triplicate groups within fifteen hapas. Five experimental diets labeled as T1 (25\% CP and NRC recommended amino acid level) as control diet, T2 (with 2\% low protein and 5\% amino acid supplementation), T3 (with $2 \%$ low protein and 10\% amino acid supplementation), T4 (with $4 \%$ low protein and 10\% amino acid supplementation) and T5 (with $4 \%$ low protein and 20\% amino acid supplementation) were prepared. Fish were fed with@3\% of their body weight twice a day at 10.00 \& 16:00 hour. Significantly higher percent weight gain (420.18 $\pm 66.84 \mathrm{a}$ ) and specific growth rate ( $13499.33 \pm 1273.54 \mathrm{a}$ ) along with improved feed conversion ratio $(1.29 \pm 0.09 \mathrm{~b})$ and hundred percent survivals were recorded during the trial. Furthermore proximate analysis of meat showed significant improvement in the crude protein level ( $81.77 \pm 0.19$ a) served with diet containing $20 \%$ limiting amino acids mixture. Therefore, limiting amino acids can be a source of cost effective feed and use safely in $L$. rohita diet.

Keywords: limiting, growth, feed conversion ratio, Labeo rohita, proximate.

Resumo

O estudo de 90 dias foi realizado em hapas instalados em tanques de terra. Peixes com peso inicial médio (220 g) foram distribuídos uniformemente em grupos triplicados em 15 hapas. Cinco dietas experimentais rotuladas como T1 (25\% de CP e NRC recomendado nível de aminoácidos) como dieta controle, T2 (com 2\% de proteína baixa e 5\% de suplementação de aminoácidos), T3 (com 2\% de proteína baixa e 10\% de suplementação de aminoácidos), T4 (com 4\% de baixa proteína e $10 \%$ de suplementação de aminoácidos) e T5 (com 4\% de baixa proteína e $20 \%$ de suplementação de aminoácidos) foram preparadas. Os peixes foram alimentados com $3 \%$ do seu peso corporal duas vezes por dia às $10 \mathrm{~h} 00$ e $16 \mathrm{~h} 00$. Ganho de peso significativamente maior $(420,18 \pm 66,84 \mathrm{a})$ e taxa de crescimento específico (13499,33 $\pm 1273,54$ a $)$ juntamente com taxa de conversão alimentar melhorada $(1,29 \pm 0,09$ b) e sobrevivência de cem por cento foram registrados durante o ensaio. Além disso, a análise aproximada da carne mostrou melhora significativa no nível de proteína bruta $(81,77 \pm 0,19$ a $)$ servida com dieta contendo $20 \%$ de mistura de aminoácidos limitantes. Portanto, a limitação de aminoácidos pode ser uma fonte de alimentação econômica e usada com segurança na dieta de $L$. rohita.
\end{abstract}

Palavras-chave: limite, crescimento, conversão alimentar, Labeo rohita, próximo.

\section{Introduction}

One approach to enhance the ability of survival of aquaculture is to decrease the protein level in the fish feeds (Wilson, 2002). This strategy will not only reduce the feed cost but also reduce environmental implications and sustain economic development of fish by providing

less nitrogenous content. The nutritional factors obviously affect the overall growth of fish along with other environmental and genetic factors. The physique of the fish retains nutritional requirements in a constant flux as these requirements may change due to different factors

*e-mail: fayyazrasool@uvas.edu.pk; drfayyaz1980@gmail.com

Received: March 4, 2021 - Accepted: April 7, 2021 
like environmental circumstances, disconcertion to fish health and age or size of fish (Lovell, 2002). Protein is the most important ingredient of fish feed and it constitutes fifty to sixty percent of feed cost in aquaculture industry (Wilson, 2002). For better and economical production of fish it is essential to provided and formulated feed with respect to analytical amino acids balance and digestible energy (NRC, 2011). Lysine, methionine and threonine are the limited feed source to fish in warm water body (Lovell, 1989; Bodin et al., 2008). In the fully intensive and semi-intensive fish culture Lysine supplemented diet increased weight gain and reduced fat content in muscles of Ictalurus punctatus and Cyprinus carpio (Robinson et al., 1980; Robinson, 1991; Viola and Lahav, 1991; Robinson and Li, 1994; Zarate and Lovell, 1997; Nguyen et al., 2013). The main functions of methionine were well studied in fish (Li et al., 2009) where methionine act as precursor of taurine, choline and other processes of metabolism (Fang et al., 2002). Insufficient amount of methionine and threonine in the diet of Paralichthys olivaceus deprived growth and feed utilization (Alam et al., 2000; Alam et al., 2003) along with poor deposition of protein in Cirrhinus mrigala (Ahmed et al., 2004). The absorption of nutrients and digestion of food significantly enhance the growth process of fish (Gisbert et al., 2009). Only one report is available which describes the effect of dietary threonine on absorptive and digestive capability of fish. This depicts that dietary threonine improved the activities of lipase, alpha amylase and trypsin in the intestine and hepatopancreas of Cyprinus carpio and enhanced the activities of intestinal enzymes related to absorption (Feng et al., 2013). The results of the present research work will help in the production of cost effective feed for $L$. rohita fish.

\section{Materials and methods}

\subsection{Diet preparation}

Five experimental diets were prepared by using fish meal, maize, corn gluten $60 \%$, soybean meal, soybean oil, di-calcium phosphate (DCP), methionine, lysine, threonine and vitamin mineral premix. Diet T1 (25\% CP and NRC recommended amino acid level) as a control diet, Diet T2 (2\% low of protein with $5 \%$ amino acid supplementation), Diet T3 (2\% of low protein with $10 \%$ amino acid supplementation), Diet T4 (4\% low of protein with $10 \%$ amino acid supplementation), and Diet T5 (4\% low of protein with $20 \%$ amino acid supplementation) Table 1 . All these feed ingredients were ground and then mixed well to form dough and used to make $3 \mathrm{~mm}$ size pellets. These pellets were then sun dried before serving to the experimental fish.

\subsection{Experimental design}

L. rohita fish were picked up from the fish hatchery unit of University of Veterinary and Animal Sciences, Ravi Campus Pattoki, Pakistan. Fish were shifted in oxygen filled carrier bags. Protecting bath were given with potassium permanganate solution (1:3000) and stocked in hapas for ninety days installed at earthen ponds. At the rate of $3 \%$ of body weight, these fish were served to satiation using experimental diets two times a day at 10:00 \& 16:00 hour throughout the experimental duration. Fish (average initial weight $220 \mathrm{~g}$ ) were weighed and stocked evenly in fifteen experimental hapas @15 fish per replica.Triplicate sets of fish were used to evaluate each practical diet. No practical diets were given to $L$. rohita at sampling day. Fortnight weight of fish were recorded with the help of weight balance (ACS-40) and scaled six times during the trial. Experimental diet allowances were readjusted according to body weight gain of fish. The provisions of continuous flow of water in all experimental hapas were furnished with constant aeration to keep level of dissolved oxygen above saturation level. Temperature and dissolve oxygen levels were monitored on daily basis.

\subsection{Samples collection}

At the end of 90 days of experimental trial, L. rohita fish from all experimental hapas were weighed individually. To check the chemical composition in fillet of fish, five fish per hapa were saved for further analysis.

\subsection{Growth and nutrient utilization parameters}

Parameters shown below were calculated according to the methods prescribed by (Hopkins, 1992) to evaluate the growing performance of $L$. rohita.

$$
\text { Weight Gain } \%=\frac{\text { Final Body Weight-Initial Body Weight }}{\text { Initial Body Weight }} \times 100
$$

$$
\begin{gathered}
\text { Specific } \\
\text { growth rate }(S G R)
\end{gathered}=\frac{(\text { In Final Wet Body Weight })-(\text { In Initial Wet Body Weight })}{\text { No.of days }} \times 100
$$

$$
\text { Feed Conversion Ratio }(F C R)=\frac{\text { Feed intake }(\mathrm{g})}{\text { Weight gain }(\mathrm{g})}
$$

Fish Survival: $\mathrm{S}=100 \mathrm{X}(\mathrm{LC} / \mathrm{LS})$

\section{$\mathrm{S}=$ Stands for survival (\%)}

$\mathrm{LC}=$ Number of fish recovered at the end of the experiment. $\mathrm{LS}=$ Number of fish stocked at the start of the experiment.

\subsection{Economic analysis}

Economic analysis of fish fry feed was analyzed in terms of economic conversion ratio (ECR) (Sánchez Lozano et al., 2007).

$$
E C R=F C R \times \text { Feed Price }
$$

\subsection{Proximate analysis}

To evaluate the chemical composition in the meat of L. rohita moisture content, crude protein, crude lipids and ash contents were calculated by standard methods (AOAC, 2006). To determine the percentage of moisture content, the samples were dehydrated in an oven at $105^{\circ} \mathrm{C}$ up to constant weight. The crude protein $(\mathrm{N} \times 6.25)$ was estimated in the samples with Kjeldhal method. Estimation was done by digesting the samples with concentrated sulphuric acid 
Table 1. Feed ingredients and calculated nutrients used in fish diets.

\begin{tabular}{|c|c|c|c|c|c|}
\hline \multirow{2}{*}{ Ingredients } & T1 & T2 & T3 & T4 & T5 \\
\hline & \multicolumn{5}{|c|}{ Inclusion levels\% } \\
\hline Maize & 60.00 & 62.00 & 62.00 & 62.90 & 62.90 \\
\hline Soybean meal & 5.00 & 5.00 & 4.80 & 4.80 & 4.80 \\
\hline Corn gluten $60 \%$ & 4.00 & 4.00 & 4.00 & 4.00 & 4.00 \\
\hline Fish meal & 20.00 & 18.22 & 18.00 & 17.10 & 16.50 \\
\hline DCP (Di-Calcium Phosphate) & 0.5 & 0.25 & 0.25 & 0.25 & 0.44 \\
\hline Soybean oil & 6.00 & 6.00 & 6.00 & 6.00 & 6.00 \\
\hline Threonine & 1.00 & 1.05 & 1.10 & 1.10 & 1.20 \\
\hline Lysine & 2.05 & 2.15 & 2.25 & 2.25 & 2.46 \\
\hline Methionine & 1.03 & 1.08 & 1.13 & 1.13 & 1.23 \\
\hline vitamin mineral premix & 0.42 & 0.25 & 0.47 & 0.47 & 0.47 \\
\hline Total & 100 & 100 & 100 & 100 & 100 \\
\hline \multicolumn{6}{|l|}{ Calculated Nutrients } \\
\hline ME ( Metabolizeable Energy) & 3708 & 3717 & 3711 & 3709 & 3701 \\
\hline $\mathrm{CP}$ (Crude Protein) & 25.00 & 24.50 & 24.50 & 24.00 & 24.00 \\
\hline Lysine & 2.27 & 2.27 & 2.30 & 2.27 & 2.36 \\
\hline Methionine & 1.41 & 1.44 & 1.48 & 1.46 & 1.54 \\
\hline Threonine & 1.71 & 1.72 & 1.75 & 1.74 & 1.81 \\
\hline Total Limiting amino acids in mixture (\%) & 4.08 & 4.28 & 4.48 & 4.48 & 4.89 \\
\hline Total Limiting amino acids in diet & 5.39 & 5.43 & 5.53 & 5.47 & 5.71 \\
\hline
\end{tabular}

\section{Calculations:}

\section{$\mathrm{CP}=25 \%$}

T1=NRC (National Research Council) requirements (Control Diet)

$\mathrm{T} 2=$ Low $\mathrm{CP}$ ( $2 \%$ of protein $)$ with $5 \%$ increased amino acid supplementation

T3=Low CP (2\% of protein) with $10 \%$ increased amino acid supplementation

T4=Low CP (4\% of protein) with $10 \%$ increased amino acid supplementation

T5=Low CP (4\% of protein) with $20 \%$ increased amino acid supplementation
Lysine $=2.05 \%$

Methionine $=1.03 \%$

Threonine $=1 \%$

Low CP ( $2 \%$ of protein): $25 / 100 * 2=0.5,25-0.5=24.5 \%$

Lysine $=2.05 / 100 * 5=0.10,2.05+0.10=2.15 \%$

Methionine $=1.03 / 100 * 5=0.05,1.03+0.05=1.08 \%$

Threonine $=1 / 100 * 5=0.05,1+0.05=1.05 \%$

Low CP ( $2 \%$ of protein): $25 / 100 * 2=0.5,25-0.5=24.5 \%$

Lysine $=2.05 / 100 * 10=0.20,2.05+0.20=2.25 \%$

Methionine $=1.03 / 100 * 10=0.10,1.03+0.10=1.13 \%$

Threonine $=1 / 100 * 10=0.1,1+0.1=1.1 \%$

Low CP ( $4 \%$ of protein): $25 / 100 * 4=1,25-1=24 \%$

Lysine $=2.05 / 100 * 10=0.20,2.05+0.20=2.25 \%$

Methionine $=1.03 / 100 * 10=0.10,1.03+0.10=1.13 \%$

Threonine $=1 / 100 * 10=0.1,1+0.1=1.1 \%$

Low CP ( $4 \%$ of protein): $25 / 100 * 4=1,25-1=24 \%$

Lysine $=2.05 / 100 * 20=0.41,2.05+0.41=2.46 \%$

Methionine $=1.03 / 100 * 20=0.20,1.03+0.20=1.23 \%$

Threonine $=1 / 100 * 20=0.2,1+0.2=1.2 \%$

Note: Symbol * means multiply. 
in a semi-automated Kjeldhal System (Made by Technico Scientific Supply). The ether extraction method was adopted by using a Soxhlet apparatus for the estimation of crude lipids in the samples. The ash content of the samples was calculated by incinerating these samples for 24 hours in a muffle furnace at a temperature of $550^{\circ} \mathrm{C}$.

\subsection{Statistical analysis}

Data for $L$. rohita fish for every replicate was checked. The results were then presented as mean \pm standard error. To assess the significant differences among the experimental treatments, data was subjected to one-way ANOVA as preliminary way. It was observed that the treatment effects were significant for the variables, feed conversion ratio (FCR), percent weight gain (PWG), specific growth rate (SGR), whole body protein, moisture, fat and ash due to supplementation of lysine, methionine \& threonine. Statistical analyses were performed using SAS. 9.4 (SAS, Institute Inc.) software. On observing a significant treatment effect with ANOVA, a post-hoc test (Duncan's multiple range test) was performed to compare treatment mean values (Steel et al., 1996).

\section{Results}

\subsection{Growth parameters}

Amino acids composition of experimental diets was measured through analysis and is presented in Table 2. Percent weight gain (Equation 1) and specific growth rate (Equation 2) showed similar significant differences among all the treatments Table 3. On the completion of ninety days of feeding trial zootechnical performance of L. rohita showed significant results due to limiting amino

Table 2. Amino acids composition of experimental diets.

\begin{tabular}{|c|c|c|c|c|c|}
\hline Amino acids & T1 (control) & TttttttT T2 & T3 & T4 & T5 \\
\hline Glutamic acid & 0.22 & 0.18 & 0.18 & 0.18 & 0.18 \\
\hline Aspartic acid & 0.26 & 0.20 & 0.20 & 0.21 & 0.21 \\
\hline Serine & 0.33 & 0.24 & 0.24 & 0.25 & 0.24 \\
\hline Glycine & 0.37 & 0.28 & 0.28 & 0.28 & 0.28 \\
\hline Alanine & 0.40 & 0.31 & 0.31 & 0.31 & 0.31 \\
\hline Cystein & 0.63 & 0.23 & 0.23 & 0.22 & 0.22 \\
\hline Proline & 0.64 & 0.34 & 0.34 & 0.34 & 0.34 \\
\hline Tyrosine & 1.03 & 0.69 & 0.69 & 0.67 & 0.66 \\
\hline Histidine & 1.06 & 0.60 & 0.59 & 0.58 & 0.57 \\
\hline Methionine & 1.19 & 0.48 & 0.48 & 0.47 & 0.46 \\
\hline Lysine & 1.37 & 0.96 & 0.95 & 0.92 & 0.90 \\
\hline Threonine & 1.61 & 0.86 & 0.85 & 0.83 & 0.82 \\
\hline Isoleucine & 1.73 & 0.87 & 0.85 & 0.83 & 0.82 \\
\hline Arginine & 1.87 & 1.13 & 1.12 & 1.09 & 1.07 \\
\hline Valine & 2.04 & 1.03 & 1.01 & 0.99 & 0.98 \\
\hline Phenylalanine & 2.37 & 0.97 & 0.96 & 0.94 & 0.93 \\
\hline Leucine & 3.76 & 1.77 & 1.75 & 1.73 & 1.71 \\
\hline
\end{tabular}

Table 3. Feed conversion ratio, specific growth rate, percent weight gain and survival rate at ninety days of feeding of Labeo rohita fed different percentages of limiting amino acids at an average temperature of $34.86^{\circ} \mathrm{C}$.

\begin{tabular}{|c|c|c|c|c|c|}
\hline Parameter & T1 (Control) & $\mathbf{T} 2$ & T3 & T4 & T5 \\
\hline $\begin{array}{c}\text { Feed conversion } \\
\text { ratio }\end{array}$ & $1.55 \pm 0.02 \mathrm{a}$ & $1.43 \pm 0.06 \mathrm{ab}$ & $1.37 \pm 0.07 \mathrm{ab}$ & $1.41 \pm 0.01 \mathrm{ab}$ & $1.29 \pm 0.09 b$ \\
\hline $\begin{array}{l}\text { Specific growth } \\
\text { rate }\end{array}$ & $8000.33 \pm 456.29 c$ & $9467.00 \pm 491.43 b c$ & $12406.00 \pm 890.79 a$ & $11293.33 \pm 253.35 a b$ & $13499.33 \pm 1273.54 a$ \\
\hline $\begin{array}{l}\text { Percent weight } \\
\text { gain }\end{array}$ & $253.54 \pm 13.82 c$ & $297.98 \pm 14.89 b c$ & $387.05 \pm 26.99 a$ & $363.43 \pm 2.97 \mathrm{ab}$ & $420.18 \pm 66.84 a$ \\
\hline$\%$ Survival rate & 100 & 100 & 100 & 100 & 100 \\
\hline
\end{tabular}

The average values, obtained from triplicate \& expressed as: Mean \pm Standard Error. Values with different superscripts in same row differ significantly $(\mathrm{P}<0.05)$. 
Table 4: Economic evaluation of Labeo rohita feed on the completion of ninety days nutritional trial.

\begin{tabular}{cccccc}
\hline Parameter & T1 (control) & T2 (5\%AA) & T3 (10\%AA) & T4 (10\%AA) & T5 (20\%AA) \\
\hline Mean initial weight $(\mathrm{g})$ & 220 & 220 & 220 & 220 & 220 \\
Mean final weight $(\mathrm{g})$ & 388.58 & 437.78 & 535.75 & 498.66 & 572.2 \\
Mean total feed intake $(\mathrm{g})$ & 13009.14 & 9154.99 & 17431.54 & 1209.02 & 16724.12 \\
Mean daily feed intake $(\mathrm{g})$ & 929.01 & 1001.9 & 1245.11 & 1209.06 & 1266 \\
Feed conversion ratio & 1.55 & 1.43 & 1.37 & 1.41 & 1.29 \\
Feed cost in Pakistani rupee/100g & 92.44 & 86.81 & 86.66 & 86.26 & 86.63 \\
Feed cost in US Dollar/100g & 0.59 & 0.55 & 0.55 & 0.55 & 0.55 \\
Economic Conversion Ratio & $143.97 \pm 2.61 \mathrm{a}$ & $124.30 \pm 5.38 \mathrm{~b}$ & $119.15 \pm 6.38 \mathrm{~b}$ & $121.62 \pm 0.86 \mathrm{~b}$ & $112.21 \pm 8.02 \mathrm{~b}$ \\
\hline
\end{tabular}

Table 5. Carcass traits of Labeo rohita after 90 days fed with control, 5\%,10\%, 10\% and 20\% amino acid supplementation.

\begin{tabular}{cccccc}
\hline Parameter & T1(Control) & T2 & T3 & T4 & T5 \\
\hline Ash\% & $14.23 \pm 0.14 \mathrm{ab}$ & $14.38 \pm .38 \mathrm{abc}$ & $13.85 \pm .38 \mathrm{bc}$ & $15.93 \pm 0.31 \mathrm{a}$ & $13.05 \pm 0.06 \mathrm{c}$ \\
Lipid\% & $5.58 \pm 0.11 \mathrm{ab}$ & $5.29 \pm 0.08 \mathrm{bc}$ & $5.72 \pm 0.15 \mathrm{a}$ & $5.28 \pm 0.09 \mathrm{bc}$ & $5.13 \pm 0.01 \mathrm{c}$ \\
Moisture\% & $0.46 \pm 0.02 \mathrm{a}$ & $0.51 \pm 0.04 \mathrm{a}$ & $0.46 \pm 0.02 \mathrm{a}$ & $0.19 \pm 0.08 \mathrm{~b}$ & $0.31 \pm 0.01 \mathrm{~b}$ \\
Dry Matter\% & $99.54 \pm 0.01 \mathrm{a}$ & $99.49 \pm 0.02 \mathrm{a}$ & $99.54 \pm 0.02 \mathrm{a}$ & $99.81 \pm 0.01 \mathrm{a}$ & $99.69 \pm 0.01 \mathrm{a}$ \\
Protein\% & $79.10 \pm 0.31 \mathrm{c}$ & $80.31 \pm 0.33 \mathrm{~b}$ & $78.40 \pm 0.31 \mathrm{c}$ & $76.45 \pm 0.10 \mathrm{~d}$ & $81.77 \pm 0.19 \mathrm{a}$ \\
\hline
\end{tabular}

The average values, obtained from triplicate \& expressed as: Mean \pm Standard Error. Values with different superscripts in same row differ significantly $(\mathrm{P}<0.05)$.

Table 6. Average values of water quality parameters observed during the ninety days of feeding period.

\begin{tabular}{ccc}
\hline Treatments & $\begin{array}{c}\text { Temperature } \\
\left({ }^{\circ} \mathbf{C}\right)\end{array}$ & $\begin{array}{c}\text { Dissolve Oxygen } \\
(\mathbf{m g} / \mathbf{L})\end{array}$ \\
\hline T1 & $34.90 \pm 0.01 \mathrm{a}$ & $5.83 \pm 0.04 \mathrm{a}$ \\
T2 & $34.88 \pm 0.04 \mathrm{a}$ & $5.82 \pm 0.05 \mathrm{a}$ \\
T3 & $34.85 \pm 0.03 \mathrm{a}$ & $5.89 \pm 0.04 \mathrm{a}$ \\
T4 & $34.84 \pm 0.04 \mathrm{a}$ & $5.85 \pm 0.04 \mathrm{a}$ \\
T5 & $34.87 \pm 0.04 \mathrm{a}$ & $5.85 \pm 0.04 \mathrm{a}$ \\
\hline
\end{tabular}

The average values, obtained from triplicate $\&$ expressed as: Mean \pm Standard Error.

acids supplementation in low crude protein diets Table 3. Feed conversion ratio (Equation 3 ) showed significant results among the treatments due to limiting amino acids supplementation. Significantly improved value of feed conversion ratio $(1.29 \pm 0.09 \mathrm{~b})$ was recorded in treatment five. As the significant increased value of percent weight gain and specific growth rate was recorded in the treatment served with twenty percent limiting amino acids supplementation. Survival rate (Equation 4) of experimental fish throughout the trail was hundred percent.

\subsection{Economic analysis}

Economic conversion ratio (ECR) (Equation 5) showed notable results between the experimental diets Table 4. Increased value of economic conversion ratio $(143.97 \pm 2.61 \mathrm{a})$ was recorded in $\mathrm{T} 1$. The estimated prices of the experimental diets (per 100g) were Rs, 92.44/- (T1, control), Rs, 86.81/- (T2), Rs, 86.66/- (T3), Rs, 86.26/- (T4) and Rs, 86.63/- (T5) Table 5.

\subsection{Carcass composition}

Whole body carcass crude protein showed significant results among all the treatments Table 5 . Significantly increased value of protein $(81.77 \pm 0.19 \mathrm{a})$ with the significantly decreased value of lipid content $(5.13 \pm 0.01$ c $)$ was recorded in the treatment served with twenty percent limiting amino acids supplementation Table 5. Body lipids and ash content showed significant differences among the treatments due to amino acids supplementation. Dry matter content showed slight variations with non-significant difference among feeding regimes. Significantly highest value of moisture content $(0.51 \pm 0.04 a)$ was recorded in the treatment served with five percent limiting amino acids supplementation Table 5.

\subsection{Water quality parameters}

In present experiment minimum and maximum ranges for dissolve oxygen and temperature were $5.82 \pm 0.05 \mathrm{a}$ and $5.89 \pm 0.04 a, 34.84 \pm 0.04$ a and $34.90 \pm 0.01$ a respectively Table 6.

\section{Discussion}

Zootechnical performance of fish is linked with feed quantity as well as feed quality. This research work elaborates the first validation in Pakistan to the best of our knowledge about the nutritional requirements of limiting 
amino acids in Indian major carp, L. rohita. Present ninety days experimental feeding trial was planned to evaluate the effect of limiting amino acids in low crude protein diets on growth and carcass composition of L rohita fish. Growth parameters and feed conversion ratio were significantly affected by the supplementation of limiting amino acids in low crude protein diets. Highest percent weight gain (420.18 $\pm 66.84 a)$, and specific growth rate (15406.67 $\pm 1415.04 a$ ) was recorded in the treatment served with $20 \%$ limiting amino acids. Although percent weight gain and specific growth rate were increased significantly in all treatments with the increased levels amino acids. Furthermore results of this study showed significantly improved feed conversion ratio in the treatment number two and five served with $10 \%$ and $20 \%$ limiting amino acids respectively. Our results are in line with the very recent finding of (Lee et al., 2020) observed similar results in Oncorhynchus mykiss Walbaum with the increasing levels of limiting amino acid, lysine in the diet. Maximum weight gain $(1572 \pm 32.2 \mathrm{a})$, Specific growth rate $(3.35 \pm 0.02 \mathrm{a})$ and improved feed conversion ratio $(0.86 \pm 0.003 b)$ were recorded in the treatment served with augmented level of dietary lysine. Findings of (Lu et al., 2014) recorded the highest value of weight gain, feed efficiency ratio and specific growth rate in the treatment with higher level of limiting amino acid methionine in fish diet. In this study maximum specific growth rate, improved feed efficiency ratio and percent weight gain was observed in the treatment served with $20 \%$ amino acid supplementation these results are closely related with the findings of (Guroy et al., 2017) reported similar results in Argyrosomus regius and found the maximum final mean weight gain and specific growth rate in the treatment supplemented with limiting lysine \& methionine in the diet. However, the repercussion of (Hong et al., 2015) further supported the results of the present study as the previous experiment pointed out that Ctenopharyngodon Idella fed with the diets supplemented having graded level of limiting amino acid threonine. Proximate analysis of experimental fish, $L$. rohita fed with limiting amino acids supplementation in low crude protein diets revealed the significantly higher crude protein level $(81.77 \pm 0.19$ a) while significantly lower lipid level $(5.13 \pm 0.01 \mathrm{c})$ were recorded in the treatment served with $20 \%$ limiting amino acids. Good quality products are assessed by the increase in protein content and in present study protein content increased significantly due to twenty percent limiting amino acids supplementation. Our findings are similar with the results of (Sardar et al., 2009 ) in which $L$. rohita showed the maximum value of weight gain, specific growth rate, protein efficiency and crude protein in the treatment served with maximum level of limiting amino acids, lysine \& methionine in fish diet. The results of this study are further supported by (Figueiredo-Silva et al., 2015) in which hybrid tilapia showed the highest level of crude protein in the treatment given the experimental diet with maximum level of threonine, methionine \& lysine during the experimental trial. In this research trial crude protein level was increased with the increased level of limiting amino acids while lipid level and ash content was decreased. This decreased content of lipids in $L$. rohita fillet might be linked to boost up the utilization of protein at production site due to appropriate provision of amino acids in diet. Similar to this study results (Zehra and Khan, 2016) observed the same findings in their trial when fed Catla catla fish with the increasing levels of threonine in the diet. Recent findings of (Li et al., 2020) showed the similar results with the present study when they served Ictalurus punctatus with the graded levels of lysine in low crude protein diets. The proximate analysis of fish carcass showed the similar results. Crude protein level was increased with the increasing level of supplemented lysine while the lipid, ash and moisture content were decreased. These results support the results of this study. Hence it is concluded that supplementation of $20 \%$ limiting amino acids with four percent low crude protein in the diet of $L$. rohita showed improved feed conversion ratio, increased percent weight gain, specific growth rate and improved crude protein content in the meat of fish. So it can be safely used in the feed of this fish and it will helpful to reduce the cost in aqua industry and will improve the fish quality. Water quality parameters were maintained within suitable ranges during the trial and well supported by the findings of (Ali et al., 2000; Abid and Ahmad, 2009a, b). Cost evaluation analysis was made to access the cost effectiveness of the experimental diets. The results demonstrate that the limiting amino acids supplementation based diets for $L$. rohita fish can make the diets cost effective. Highest weight gain with low cost (86.63) diet was observed in the treatment served with twenty percent amino acids supplementation as compared to other treatments. Low economic conversion ratio (112.21 $\pm 8.02 \mathrm{~b})$ was also recorded in the same treatment. Therefore this study assesses the feasibility of decreasing feed cost by incorporating different percentages of limiting amino acids. These results are in line with the findings of (ElHaroun and Bureau 2007; El-Haroun et al., 2009) reported for the cost effective commercial fish feed by balancing the essential amino acids with adequate protein content in the feed. Furthermore (Zhu et al., 2011) concluded that to meet the fish nutritional requirement and to prepare cost effective diet optimum amount of essential amino lysine is necessary.

\section{References}

ABID, M. and AHMAD, M.S., 2009a. Growth response of Labeo rohita fingerlings fed with different feeding regimes under intensive rearing. Journal of Animal and Plant Science, vol. 19, no. 1, pp. 25-49.

ABID, M. and AHMAD, M.S., 2009b. Efficacy of feeding frequency on growth and survival of Labeo rohita (Ham) fingerling under intensive rearing. Journal of Animal and plant Science, vol. 19, pp. 111-113.

AHMED, I., KHAN, M.A. and JAFRI, A., 2004. Dietary threonine requirement of fingerling Indian major carp, Cirrhinus mrigala (Hamilton). Aquaculture Research, vol. 35, no. 2, pp. 162-170. http://dx.doi.org/10.1111/j.1365-2109.2004.00997.x.

ALAM, M., TESHIMA, S., KOSHIO, S., YOKOYAMA, S. and ISHIKAWA, M., 2003. Optimum dietary threonine level for juvenile Japanese flounder (Paralichthys olivaceus). Asian Fisheries Science, vol. 16 , no. $1-2$, pp. $175-184$. 
ALAM, M.S., TESHIMA, S., ISHIKAWA, M. and KOSHIO, S., 2000. Methionine requirement of juvenile Japanese flounder (Paralichthys olivaceus). Journal of the World Aquaculture Society, vol. 31, no. 4, pp. 618-626. http://dx.doi. org/10.1111/j.1749-7345.2000.tb00911.x.

ALI, M., SALAM, A., AZEEM, A., SHAFIQ, M. and KHAN, B.A., 2000. Studies on the effect of seasonal variations on physical and chemical characteristics of mixed water from river ravi and Chenab at union site in Pakistan. Journal of Scientific Research, vol. 11, pp. 1-17.

ASSOCIATION OF OFFICIAL ANALYTICAL CHEMIST - AOAC, 2006. Official method of analysis. 18th ed. Washington, D.C: AOAC.

BODIN, N., MAMBRINI, M., WAUTERS, J.B., ABBOUDI, T., OOGHE, W., BOULENGE, E.L., LARONDELLE, Y. and ROLLIN, X., 2008. Threonine requirements for rainbow trout (Oncorhynchus mykiss) and Atlantic salmon (Salmo salar) at the fry stage are similar. Aquaculture (Amsterdam, Netherlands), vol. 274, no. 2-4, pp. 353-365. http://dx.doi.org/10.1016/j.aquaculture.2007.11.031.

EL-HAROUN, E.R. and BUREAU, D.P., 2007. Comparison of the bioavailability of lysine in blood meals of various origins to that of L-lysine HCL for rainbow trout (Oncorhynchus mykiss). Aquaculture (Amsterdam, Netherlands), vol. 262, no. 2-4, pp. 402-409. http://dx.doi.org/10.1016/j.aquaculture.2006.10.032.

EL-HAROUN, E.R., AZEVEDO, P.A. and BUREAU, D.P., 2009. High dietary incorporation levels of rendered animal protein ingredients on performance of rainbow trout Oncorhynchus mykiss (Walbaum, 1972). Aquaculture (Amsterdam, Netherlands), vol. 290, no. 3-4, pp. 269-274. http://dx.doi.org/10.1016/j. aquaculture.2009.02.014.

FANG, Y.Z., YANG, S. and WU, G.Y., 2002. Free radicals, antioxidants, and nutrition. Nutrition (Burbank, Los Angeles County, Calif.), vol. 18, no. 10, pp. 872-879. http://dx.doi.org/10.1016/S08999007(02)00916-4. PMid:12361782.

FENG, L., PENG, Y., WU, P., HU, K., JIANG, W.D., LIU, Y., JIANG, J., LI, S.H. and ZHOU, X.Q., 2013. Threonine affects intestinal function, protein synthesis and gene expression of TOR in Jian carp (Cyprinus carpio var. Jian). PLoS One, vol. 8, no. 7, pp. e69974. http://dx.doi.org/10.1371/journal.pone.0069974. PMid:23922879.

FIGUEIREDO-SILVA, C., LEMME, A., SANGSUE, D. and KIRIRATNIKOM, S., 2015. Effect of DL-methionine supplementation on the success of almost total replacement of fish meal with soybean meal in diets for hybrid tilapia (Oreochromis niloticus $\times$ Oreochromis mossambicus). Aquaculture Nutrition, vol. 21, no. 2, pp. 234-241. http://dx.doi.org/10.1111/anu.12150.

GISBERT, E., GIMENEZ, G., FERNANDEZ, I., KOTZAMANIS, Y. and ESTEVEZ, A., 2009. Development of digestive enzymes in common dentex Dentex dentex during early ontogeny. Aquaculture (Amsterdam, Netherlands), vol. 287, no. 3-4, pp. 381-387. http://dx.doi.org/10.1016/j.aquaculture.2008.10.039.

GUROY, D., KARADAL, O., GUROY, B., MANTOGLU, S., CELEBI, K., SIMSEK, O., EROLDOGAN, O.T., GENC, M.A. and GENC, E., 2017. The effects of dietary protein levels with amino acid supplementation on the growth performance, haematological profile and histology of meagre (Argyrosomus regius) in two different size classes. Aquaculture Research, vol. 48, no. 12, pp. 5751-5764. http://dx.doi.org/10.1111/are.13398.

HONG, Y., JIANG, W., KUANG, S., HU, K., TANG, L., LIU, Y., JIANG, J., ZHANG, Y., ZHOU, X. and FENG, L., 2015. Growth, digestive and absorptive capacity and antioxidant status in intestine and hepatopancreas of sub-adult grass carp Ctenopharyngodonidella fed graded levels of dietary threonine. Journal of Animal Science and Biotechnology, vol. 6, no. 1, pp. 34. http://dx.doi.org/10.1186/ s40104-015-0032-1.
HOPKINS, K.D., 1992. Reporting fish growth: a review of the Basics 1. Journal of the World Aquaculture Society, vol. 23, no. 3, pp. 173-179. http://dx.doi.org/10.1111/j.1749-7345.1992.tb00766.x.

LEE, S., SMALL, B.C., PATRO, B., OVERTURF, K. and HARDY, R.W., 2020. The dietary lysine requirement for optimum protein retention differs with rainbow trout (Oncorhynchus mykiss Walbaum) strain. Aquaculture (Amsterdam, Netherlands), vol. 514, pp. 734483. http://dx.doi.org/10.1016/j.aquaculture.2019.734483.

LI, M.H., BOSWORTH, B.G. and LUCAS, P.M., 2020. Effects of available lysine concentrations in 28 and $32 \%$ protein diets on growth, feed efficiency, processing yield, and fillet composition of pond-raised channel catfish, Ictalurus punctatus. Journal of the World Aquaculture Society, vol. 51, no. 1, pp. 235-243. http:// dx.doi.org/10.1111/jwas.12644.

LI, P., MAI, K.S., TRUSHENSKI, J. and WU, G.Y., 2009. New developments in fish amino acid nutrition: towards functional and environmentally oriented aquafeeds. Amino Acids, vol. 37, no. 1, pp. 43-53. http://dx.doi.org/10.1007/s00726-008-0171-1. PMid:18751871.

LOVELL, R.T., 2002. Diet and fish husbandry. In: J.E. HALVER and R.W. HARDY, eds. Fish nutrition. New York, NY: Academic Press, pp. 703-754.

LOVELL, T., 1989. Nutrition and feeding of fish. New York, NY: Van Nostrand-Reinhold, vol. 260. http://dx.doi.org/10.1007/9781-4757-1174-5.

LU, J., HUA, Y., FU, W.Z., ZHOU, F., YANG, B.B., XIAO, J.X., LIU, M.H. and SHAO, Q.J., 2014. Effects of supplementation coated lysine and methionine in mixture protein diets on growth performance, digestibility and serum biochemical indices of juvenile black sea bream, Acanthopagrus schlegelii. Turkish Journal of and Aquatic Sciences., vol. 14, no. 3, pp. 633-642. http://dx.doi. org/10.4194/1303-2712-v14_3_05.

NATIONAL RESEARCH COUNCIL - NRC, 2011. Nutrient requirements of fish and shrimp. Washington: The National Academies Press.

NGUYEN, M.V., JORDAL, A.E., ESPE, M., BUTTLE, L., LAI, H.V. and RøNNESTAD, I.. 2013. Feed intake and brain neuropeptide $Y$ (NPY) and cholecystokinin (CCK) gene expression in juvenile cobia fed plant-based protein diets with different lysine to arginine ratios. Comparative Biochemistry and Physiology, vol. 165, no. 3, pp. 328-337. http://dx.doi.org/10.1016/j.cbpa.2013.04.004. PMid:23587878.

ROBINSON, E.H. and LI, M.H., 1994. Use of plant protein in catfish feeds: replacement of soybean meal with cottonseed meal and replacement of fish meal with soybean meal and cottonseed meal. Journal of the World Aquaculture Society, vol. 25, no. 2, pp. 271-276. http://dx.doi.org/10.1111/j.1749-7345.1994.tb00190.x.

ROBINSON, E.H., 1991. Improvement of cottonseed meal protein with supplemental lysine in feeds for channel catfish. Journal of Applied Aquaculture, vol. 1, no. 2, pp. 1-14. http://dx.doi. org/10.1300/J028v01n02_01.

ROBINSON, E.H., WILSON, R.P. and POE, W.E., 1980. Re-evaluation of the lysine requirement and lysine utilization by fingerling channel catfish. The Journal of Nutrition, vol. 110, no. 11, pp. 23132316. http://dx.doi.org/10.1093/jn/110.11.2313. PMid:6776245.

SÁNCHEZ LOZANO, N.B., TOMÁS VIDAL, A., MARTÍNEZ-LLORENS, S., NOGALES MÉRIDA, S., BLANCO, J.E., MOÑINO LÓPEZ, A., PLA TORRES, M. and CERDÁ, M.J., 2007. Growth and economic profit of gilthead sea bream (Sparus aurata, L.) fed sunflower meal. Aquaculture (Amsterdam, Netherlands), vol. 272, no. 1-4, pp. 528-534. http://dx.doi.org/10.1016/j.aquaculture.2007.07.221.

SARDAR, P., ABID, M., RANDHAWA, H.S. and PRABHAKAR, S.K., 2009. Effect of dietary lysine and methionine supplementation on growth, nutrient utilization, carcass compositions and 
haemato-biochemical status in Indian Major Carp, Rohu (Labeo rohita $\mathrm{H}$.) fed soy protein-based diet. Aquaculture Nutrition, vol. 15 , no. 4, pp. 339-346. http://dx.doi.org/10.1111/j.13652095.2008.00598.x.

STEEL, R.G.D., TORRIE, J.H. and DINKEY, D.A., 1996. Principles and procedures of statistics. 2nd ed. Singapore: McGraw Hill Book Co.

VIOLA, S. and LAHAV, E., 1991. Effects of lysine supplementation in practical carp feeds on total protein sparing and reduction of pollution. Israeli Journal of Aquaculture - Bamidgeh, vol. 43 no. 3, pp. 112-118.

WILSON, R.P., 2002. Protein and amino acids. In: J.E. HALVER and R.W. HARDY, eds Fish nutrition. San Diego, California: Academic Press, pp. 150.

ZARATE, D.D. and LOVELL, R.T., 1997. Free lysine (l-lysine $\cdot \mathrm{HCl})$ is utilized for growth less efficiently than protein-bound lysine (soybean meal) in practical diets by young channel catfish (Ictalurus punctatus). Aquaculture (Amsterdam, Netherlands), vol. 159, no. 1-2, pp. 87-100. https://doi.org/10.1016/S0044-8486(97)00184-1.

ZEHRA, S. and KHAN, M.A., 2016. Dietary threonine requirement of fingerling Indian major carp,Catla catla (H Hamilton) estimated by growth, protein retention efficiency, threonine deposition, haematological parameters and carcass composition. Aquaculture Research, vol. 47, no. 1, pp. 253-265. http://dx.doi. org/10.1111/are.12487.

ZHU, H., GONG, G., WANG, J., WU, X., XUE, M., NIU, C., GUO, L. and YU, Y., 2011. Replacement of fish meal with blend of rendered animal protein in diets for Siberia sturgeon (Acipenserbaerii Brandt) results in performance equal to fish meal fed fish. Aquaculture Nutrition, vol. 17, no. 2, pp. 389-395. http://dx.doi. org/10.1111/j.1365-2095.2010.00773.x. 